\title{
ADAPTASI POSITIF PADA RESILIENSI AKADEMIK MAHASISWA DOKTORAL
}

\author{
Wiwin Hendriani \\ Fakultas Psikologi Universitas Airlangga \\ Kampus B UNAIR, Jl. Airlangga 4-6 Surabaya \\ wiwin.hendriani@psikologi.unair.ac.id
}

\begin{abstract}
This study aimed to findout how doctoral students have academic resilience to overcome various challenge in their doctoral journey and complete all the learning process optimally. The approach chosen in this research was qualitative case study. Participants consisted of six students of Psychology Doctoral Program of Airlangga University who have successfully completed the study. The participants' study period varied from 4 to 6 years. Data collection in this research was conducted by using interview and initial data entry sheet. The thematic data driven was used in analyzing data. The results identified that doctoral students will have academic resilience if they are able to adapt positively to negative experiences during the study process. The three main negative experiences reported by participants are: The problem of time-sharing between roles, problems with mentors and examiners, and problems in conducting the research. The positive adaptation consists of two categories: By prioritizing the positive response of in stressful situations and making positive personal adjustments. Those results can further be utilized to formulate effective steps in providing more accurate mentoring process for doctoral students.
\end{abstract}

Keywords: academic resilience, doctoral student, positive adaptation

\begin{abstract}
Abstrak
Penelitian ini bertujuan untuk mengetahui bagaimana mahasiswa yang menempuh pendidikan doktor memiliki resiliensi akademik sehingga mampu mengatasi berbagai macam tantangan studi dan menyelesaikan proses belajarnya dengan baik. Pendekatan yang dipilih dalam pelaksanaan penelitian ini adalah kualitatif, dengan tipe studi kasus. Partisipan terdiri dari enam orang mahasiswa Program Studi Doktor Psikologi Universitas Airlangga yang telah berhasil menyelesaikan studi. Masa studi partisipan bervariasi dari 4 hingga 6 tahun. Pengumpulan data dalam penelitian ini dilakukan dengan menggunakan metode wawancara dengan pedoman umum dan lembar isian data awal. Sementara teknik analisis data yang digunakan pada penelitian ini adalah analisis tematik data driven. Hasil penelitian menunjukkan bahwa resiliensi akademik akan dimiliki apabila mahasiswa doktoral mampu beradaptasi secara positif terhadap berbagai pengalaman negatif yang menekan dan menghambat selama proses studi. Tiga pengalaman negatif yang utama dirasakan oleh seluruh partisipan, adalah: permasalahan pembagian waktu antar peran, permasalahan dengan pembimbing dan penguji, dan permaslahan dalam pelaksanaan penelitian. Adapun adaptasi positif yang dimaksud
\end{abstract}


terdiri dari dua kategori, yakni dengan cara mengutamakan respon perilaku positif dalam situasi yang menekan dan melakukan penyesuaian personal dalam diri individu. Hasil penelitian ini selanjutnya dapat dimanfaatkan untuk merumuskan upaya yang efektif dalam memberikan pendampingan proses studi mahasiswa doktoral secara lebih tepat.

Kata kunci: adaptasi positif, mahasiswa doctoral, resiliensi akademik,

\section{Pendahuluan}

Pendidikan Doktor adalah program pendidikan terstruktur pada strata 3 yang ditujukan untuk memperoleh gelar doktor sebagai gelar akademik tertinggi. Pendidikan doktoral merupakan puncak dari rangkaian pendidikan formal, berorientasi menghasilkan ilmuwan yang mampu mengembangkan dan menghasilkan temuantemuan di bidang ilmu pengetahuan (Peraturan Rektor Universitas Airlangga Nomor 21 Tahun 2014).

Sebagai jenjang pendidikan tertinggi, studi ini menuntut berbagai macam kemampuan dari mahasiswanya untuk dapat menghasilkan karya ilmiah berkualitas tinggi yang disebut dengan disertasi. Sejalan isi Kerangka Kualifikasi Nasional Indonesia (KKNI) yang ditetapkan oleh Presiden Republik Indonesia pada Tahun 2012, pendidikan doktor diharuskan mampu menghasilkan lulusan yang setara dengan jenjang 9 dari kualifikasi, yaitu: (1) Mampu mengembangkan pengetahuan, teknologi dan/atau seni baru, di dalam bidang keilmuannya atau praktek profesionalnya melalui riset hingga menghasilkan karya kreatif, original, dan teruji; (2) Mampu memecahkan permasalahan ilmu pengetahuan, teknologi dan/atau seni di dalam bidang keilmuannya, melalui pendekatan inter, multi dan transdisipliner; (3) Mampu mengelola, memimpin dan mengembangkan riset, dan pengembangan yang bermanfaat bagi kemaslahatan umat manusia, serta mampu mendapat pengakuan nasional dan internasional.

Melihat tingkat kesulitan dan capaian kualifikasi proses pembelajaran maupun lulusan yang harus dipenuhi, maka jumlah individu baik akademisi, peneliti maupun praktisi yang dapat menempuh pendidikan hingga jenjang doktoral juga masih relatif sedikit. Hal ini tampak dari data sedikitnya jumlah mahasiswa S3 di Indonesia dan jumlah doktor yang kemudian dihasilkan (Siregar, 2014; Sumardiyani, 2015). Pangkalan Data Pendidikan Tinggi (PD-Dikti) Kemenristekdikti Tahun 2016 mencatat lulusan doktor di Indonesia yang menjadi staf di perguruan tinggi baru berjumlah 30.051 orang. Sementara catatan Lembaga Pengelola Dana Pendidikan (LPDP), jumlah penyandang gelar doktor di Indonesia pada Tahun 2012 adalah 25.000 orang. Dua tahun kemudian angka tersebut berubah menjadi 75.000 orang. Meski mengalami kenaikan, namun angka ini jauh tertinggal dari Cina yang mampu memiliki kurang lebih 500.000 doktor. Dari setiap satu juta penduduk Indonesia hanya terdapat 143 orang doktor. Selain dengan Cina, perbandingan tersebut sangat jauh berbeda dengan negara-negara tetangga yang lain (Jumlah Doktor di Indonesia Tak Sebanding Jumlah Penduduknya, 2017).

Masih terkait tingkat kesulitan, segenap kemampuan personal akan diuji dalam pendidikan doktoral. Proses pendidikan doktoral memiliki berbagai tantangan yang tidak selalu mudah dilalui oleh mahasiswa (Bireda, 2015). Percy (2014) mengemukakan, studi doktoral merupakan sebuah tahapan ujian yang tersulit dalam 
rangkaian kehidupan akademik seseorang. Catatannya menunjukkan bahwa tidak seluruh mahasiswa yang menempuh dapat menyelesaikan jenjang pendidikan ini dengan baik. Banyak yang pada akhirnya menghabiskan waktu lama, energi dan materi yang juga terkuras, sehingga tidak sedikit yang kemudian mengalami tekanan psikologis hingga bahkan tidak mampu menyelesaikan studi (Pyhalto, Toom, Stubb, dan Lonka, 2012).

Stres tersebut diakibatkan oleh beragam sebab, antara lain: Keharusan menulis laporan penelitian dengan standar tinggi dan menghasilkan artikel ilmiah yang dipublikasikan (Sivakumaren, 2014), problem sumber daya dan hambatan dalam proses pembimbingan (Pyhalto, dkk, 2012; Ezebilo, 2012), tuntutan kualitas penelitian (Golde and Gallagher, 1999; Bireda, 2015), dan berbagai stresor yang terkait kondisi psikososial seperti adanya benturan tuntutan antara studi dengan keluarga dan pekerjaan (Pyhalto, dkk, 2012; Vekkaila, Pyhalto, dan Lonka, 2013).

Tantangan dalam menempuh pendidikan doktor juga dapat bervariasi menurut jenis kelamin mahasiswa (Leonard, 2001; Raddon, 2002). Hal ini terkait dengan perbedaan tuntutan berbagai peran sosial yang harus dipenuhi oleh masing-masing kelompok. Tingkat stres yang lebih tinggi cenderung ditunjukkan oleh mahasiswa perempuan dibandingkan laki-laki (Oswalt \& Riddock, 2007; Toews, Lockyer, Dobson, Simpson, Brownell, Brenneis, MacPherson, dan Cohen, 1997). Salah satu sebabnya adalah karena mereka juga memiliki tanggung jawab dalam keluarga, sebagai ibu, istri yang umumnya juga bekerja, dan beberapa diantaranya juga menjalankan peran sosial lain seperti merawat orangtua (Moyer, Salovey, dan Casey-Cannon, 1999; Hyun, Quinn, Madon, dan Lusting, 2006; Stratton Mielke, Kirshenbaum, Goodrich, dan McRae, 2006).

Hasil penelitian Smith, Maroney, Nelson, Lable, dan Abel (2006) menemukan bahwa mahasiswa doktoral juga memiliki banyak kekhawatiran seperti keuangan, anakanak, orang tua yang sudah berusia lanjut, serta tanggung jawab sosial yang lain termasuk hubungan dengan pasangan. Tanggung jawab yang beragam dan saling tumpang tindih dari sisi waktu pada akhirnya dapat memunculkan konflik antara peran pribadi dan peran akademik (Johnson, Batia, dan Haun, 2008; Offstein, Larson, McNeill, dan Mjoni, 2004; Raddon, 2002), mempengaruhi kesejahteraan psikologis mahasiswa yang mengalami, sehingga pada akhirnya berkonsekuensi pada kelancaran dan lamanya waktu dalam penyelesaian studi (Hyun dkk., 2006; Johnson, dkk, 2008). Penelitian tersebut sejalan dengan data riset Pyhalto, dkk. (2012) dan Vekkaila, dkk. (2013) yang menunjukkan sekian banyak mahasiswa doktoral mengalami persoalan psikologis, hingga beberapa diantaranya berakhir dengan kegagalan dalam menyelesaikan studi.

Data lain namun demikian juga menemukan adanya mahasiswa doktoral yang berhasil melalui berbagai macam rintangan sehingga mampu menyelesaikan studinya tepat waktu (Castro, dkk, 2011). Mereka mampu memusatkan perhatian dan konsentrasi pada riset yang dilakukan dengan penuh dan sungguh-sungguh, membuat strategi belajar yang tepat disertai komitmen tinggi alam melaksanakannya. Mereka yang mampu menunjukkan pengelolaan positif terhadap berbagai kondisi yang mendatangkan tekanan dan kemudian berhasil menyelesaikan studi tepat waktu adalah mahasiswa yang diketahui memiliki resiliensi dalam proses belajar, atau yang disebut sebagai resiliensi akademik (Fuerth, 2008; Boatman, 2014).

Lazarus (1993, dalam Tugade dan Fredricson, 2004) mendefinisikan resiliensi sebagai koping efektif dan adaptasi positif terhadap kesulitan dan tekanan. Sementara 
menurut Richardson (2002), resiliensi adalah proses koping terhadap stresor, kesulitan, perubahan, maupun tantangan yang dipengaruhi oleh faktor protektif. Resiliensi mencerminkan bagaimana kekuatan dan ketangguhan yang ada dalam diri seseorang. Resiliensi psikologis ditandai dengan kemampuan untuk bangkit dari pengalaman emosional yang negatif. Seorang yang resilien akan berusaha untuk menghadapi dan kemudian bangkit dari berbagai kondisi stres dengan kemampuan yang dimiliki (Block dan Kremen, 1996, dalam Tugade dan Fredricson, 2004).

Resiliensi akademik merupakan resiliensi dalam proses belajar, yakni sebuah proses dinamis yang mencerminkan kekuatan dan ketangguhan seseorang untuk bangkit dari pengalaman emosional negatif, saat menghadapi situasi sulit yang menekan atau mengandung hambatan signifikan dalam aktivitas belajar yang dilakukan. Resiliensi akademik terjadi ketika mahasiswa menggunakan kekuatan internal maupun eksternalnya untuk mengatasi berbagai pengalaman negatif, menekan dan menghambat selama proses belajar, sehingga mereka mampu beradaptasi dan melaksanakan setiap tuntutan akademik dengan baik (Boatman, 2014).

Mengetahui lebih jauh tentang bagaimana resiliensi akademik dapat dicapai, akan memberikan sumbangan besar terhadap upaya yang dapat dilakukan untuk memberikan pendampingan proses studi mahasiswa doktoral secara tepat (Boatman, 2014). Sejauh ini telah ditemukan 3 penelitian yang memotret tentang resiliensi akademik pada mahasiswa doctoral, yaitu penelitian Fuerth (2008), Castro, Cavajos, Garcia, dan Castro (2011), dan Boatman (2014), namun ketiganya dilakukan di luar Indonesia. Perbedaan tempat penelitian, terlebih pada negara yang juga berlainan rumpun, tentu akan membawa konsekuensi terhadap perbedaan situasi yang dihadapi oleh mahasiswa, kurikulum pendidikan, dan berbagai pola kebiasaan yang berlaku di dalamnya.

Apa yang dihadapi oleh mahasiswa doktoral pada ketiga penelitian tersebut boleh jadi berbeda dengan tantangan dan kesulitan yang secara spesifik dialami oleh mahasiswa doktoral di Indonesia. Disamping faktor perbedaan kurikulum, kultur yang berbeda juga akan memungkinkan terjadinya perbedaan pada upaya yang dilakukan oleh mahasiswa dalam mencapai resiliensinya sehingga mampu menyelesaikan studi tepat waktu.

Penelitian ini bermaksud untuk menindaklanjuti kebutuhan informasi tersebut dengan menggunakan pendekatan kualitatif agar dapat menghasilkan data yang kaya, yang nantinya dapat digunakan sebagai dasar perbaikan dalam pengelolaan program pendidikan doktoral. Pertanyaan utama yang diajukan adalah: Bagaimana mahasiswa yang menempuh pendidikan doktor memiliki resiliensi akademik sehingga mampu mengatasi berbagai macam tantangan studi dan menyelesaikan proses belajarnya dengan baik?

\section{Metode Penelitian}

Penelitian ini menggunakan pendekatan kualitatif. Adapun tipe penelitian yang dipilih adalah studi kasus. Data dari seluruh partisipan dalam penelitian ini akan dianalisis sebagai satu kesatuan unit. Partisipan terdiri dari enam orang mahasiswa Program Studi Doktor Psikologi Universitas Airlangga yang telah berhasil menyelesaikan studi. Masa studi partisipan bervariasi dari 4 hingga 6 tahun. 
Tabel 1.

Partisipan Penelitian

\begin{tabular}{cccc}
\hline Partisipan & Tahun Masuk & Tahun Lulus & Masa Studi \\
\hline 1 & 2010 & 2016 & 6 Tahun \\
\hline 2 & 2010 & 2016 & 6 Tahun \\
\hline 3 & 2010 & 2016 & 6 Tahun \\
\hline 4 & 2010 & 2015 & 5 Tahun \\
\hline 5 & 2010 & 2016 & 6 Tahun \\
\hline 6 & 2012 & 2016 & 4 Tahun \\
\hline
\end{tabular}

Pengumpulan data dalam penelitian ini dilakukan dengan menggunakan metode wawancara dengan pedoman umum dan lembar isian data awal. Sementara teknik analisis data yang digunakan pada penelitian ini adalah analisis tematik data driven yang dikembangkan oleh Boyatzis (1998).

\section{Hasil dan Pembahasan}

Resiliensi akademik memotret bagaimana siswa atau mahasiswa mengatasi berbagai pengalaman negatif, menekan dan menghambat selama proses belajar, sehingga berhasil memenuhi setiap tuntutan akademik dengan baik. Hasil analisis data menunjukkan bahwa pencapaian resiliensi akademik terjadi dengan adanya adaptasi positif yang mampu dimunculkan oleh mahasiswa setiap kali berhadapan dengan kesulitan. Adaptasi positif yang dimaksud akan dipaparkan dengan menjelaskan terlebih dahulu pengalaman negatif yang dirasakan partisipan dan menjadi kesulitan besar dalam proses studinya.

Terdapat tiga pengalaman negatif yang utama dirasakan oleh mahasiswa doktoral dalam penelitian ini dan cukup menguras energi mereka untuk mengatasinya. Ketiga pengalaman tersebut meliputi: (1) Problem pembagian waktu antar peran yang sedang dijalani; (2) Problem dengan pembimbing dan penguji; dan (3) Problem dalam pelaksanaan penelitian.

Seluruh partisipan menempuh studi sambil bekerja. Meskipun secara administratif terdapat dua status studi, yaitu tugas belajar dan ijin belajar, namun dalam praktiknya jumlah pekerjaan yang masih harus dipenuhi oleh partisipan selama masa studi antara kedua status tersebut tidak berbeda. Setiap kali tugas belajar dan pekerjaan datang dalam waktu yang bersamaan, maka benturan waktu antar peran pun sulit dihindarkan.

Problem kedua dengan pembimbing dan penguji juga demikian. Secara personal problem ini tidak lepas dari perbedaan karakter dan pengalaman antar individu. Sejak awal menempuh studi, mahasiswa S3 telah membawa berbagai pengetahuan dan pengalamannya sebagai akademisi maupun praktisi, yang kemudian dijadikan bekal untuk menyusun disertasi. Akan tetapi pengetahuan dan pengalaman tersebut tidak jarang justru bertentangan dengan masukan para pembimbing.

Pada problem ketiga tentang pelaksanaan penelitian, mahasiswa mengakui kelemahan ini dimiliki dan memberi hambatan signifikan dalam proses penelitian yang dilakukan. Keterbatasan penguasaan metodologi dan pengalaman lapangan menjadi catatan tersendiri yang nantinya patut dicarikan solusi agar problem serupa dapat diantisipasi sejak awal. 
Ketiga pengalaman negatif tersebut pada akhirnya mendatangkan tekanan yang cukup berat pada masing-masing partisipan. Kutipan-kutipan berikut sedikit banyak menggambarkan suasana psikologis yang dialami:

Saya merasa seperti ada jurang menganga dihadapan dan saya seolaholah tidak dapat melakukan apapun untuk melaluinya. Sempat merasa tidak percaya diri dan tidak yakin akan dapat menyelesaikan studi dengan baik (P3).

Merasa minor dan demotivasi (P1)

Saya sampai merasakan putus asa dan sangsi mampu menyelesaikan kuliah. P5)

Lebih lanjut, temuan menunjukkan adanya keterkaitan antara penekanan informasi partisipan tentang berat beban yang dirasakan dengan lama waktu yang dibutuhkan untuk menyelesaikan studi. Pada dua partisipan yang mampu menyelesaikan studi lebih cepat dari empat orang yang lain, tekanan psikologis akibat rangkaian kesulitan yang dihadapi tidak terlalu banyak disampaikan selama proses wawancara. Hal ini menjadi data menarik, memunculkan beberapa asumsi yang ke depan perlu ditindaklanjuti dalam riset-riset berikutnya: (1) Ada perbedaan resiliensi akademik pada mahasiswa jika ditinjau dari lama waktu penyelesaian studinya; (2) Terdapat perbedaan dinamika psikologis diantara mahasiswa yang memiliki perbedaan kapasitas resilien.

Partisipan menyampaikan adanya dua faktor yang turut terlibat menyangatkan maupun membantu mereduksi stres. Faktor yang dimaksud berikut penjelasannya dapat dicermati pada Tabel 2.

Tabel 2.

Faktor Risiko dan Protektif

\begin{tabular}{ccl}
\hline No. & Faktor Risiko/Protektif & \multicolumn{1}{c}{ Penjelasan } \\
\hline 1. & Persepsi Terhadap Kesulitan & Faktor ini dapat menjadi risiko maupun protektif tergantung \\
& dari isi persepsinya. Persepsi negatif (sulit, berat, dsb) yang \\
& muncul terus-menerus akan menjadi faktor internal yang \\
& berisiko menyangatkan tekanan dan semakin menghambat \\
& proses belajar. Sementara persepsi positif akan mendatangkan \\
& afirmasi yang juga positif sehingga mampu mereduksi stres \\
& dan menguatkan diri untuk terus berproses. \\
\hline Sikap Teman & Sikap teman ternyata disadari turut memberi pengaruh \\
& terhadap kondisi psikologis individu ketika tengah berhadapan \\
& dengan kesulitan. Sikap teman yang positif akan berefek \\
& menguatkan, sementara sikap negatif akan berujung \\
& memperberat tekanan yang sedang dirasakan. \\
\hline
\end{tabular}

Terhadap berbagai kesulitan silih berganti dihadapi, adaptasi positif adalah kunci bagaimana resiliensi akademik dapat tercapai, sekaligus penentu keberhasilan mahasiswa doktoral dalam menyelesaikan pendidikan. Hasil analisis menunjukkan adanya dua kategori adaptasi yang dimunculkan oleh partisipan, yaitu: (1) Mengutamakan respon perilaku positif dalam situasi yang menekan; dan (2) Melakukan penyesuaian personal dalam diri individu. Rincian bentuk adaptasi dari kedua kategori tersebut dapat dicermati pada Tabel 3. 
Tabel 3.

Adaptasi Positif Terhadap Kesulitan

\begin{tabular}{cl}
\hline No. & \multicolumn{1}{c}{ A. Respon perilaku positif dalam situasi yang menekan } \\
\hline 1. & $\begin{array}{l}\text { Membuat jadwal pelaporan kemajuan riset secara berkala pada promotor dan kopromotor, } \\
\text { serta disiplin memenuhinya }\end{array}$ \\
\hline 2. & $\begin{array}{l}\text { Mengupayakan proses konsultasi yang lebih efektif dengan menyiapkan terlebih dahulu } \\
\text { pokok pertanyaan atau ateri diskusi bersama pembimbing maupun penguji secara rinci }\end{array}$ \\
\hline 3. & $\begin{array}{l}\text { Menyegerakan diri melakukan konfirmasi untuk menghindari kesalahan pemahaman } \\
\text { terhadap masukan pembimbing atau penguji }\end{array}$ \\
\hline 4. & Menyegerakan diri untuk mengerjakan masukan/arahan yang diterima \\
\hline 5. & Mengatur alokasi waktu secara jelas dalam mengerjakan tugas-tugas dari peran yang berbeda \\
\hline 6. & Mengambil risiko untuk mengutamakan kepentingan studi \\
\hline B. & Besediaan untuk membuka diri terhadap berbagai masukan \\
\hline 2. & Mengingatkan diri pada komitmen awal saat memutuskan studi lanjut \\
\hline 3. & Mengutamakan untuk berpikir positif \\
\hline 4. & Menyadarkan diri untuk mandiri, tidak bergantung pada orang lain dalam berproses \\
\hline 5. & Persisten mengerjakan \\
\hline 6. & Menekankan kesadaran bahwa pembimbing dan penguji juga memiliki banyak tanggung \\
\hline j. & Pawab lain, untuk menghindarkan diri dari kecewa jika yang diharapkan tidak diperoleh \\
\hline
\end{tabular}

Resiliensi adalah kapasitas untuk mempertahankan kemampuan agar berfungsi secara kompeten dalam menghadapi berbagai stresor kehidupan (Kaplan dkk., 1996; Egeland dkk., 1993, dalam VanBreda, 2001). Resiliensi ditandai oleh sejumlah karakteristik, yaitu: Adanya kemampuan dalam menghadapi kesulitan, ketangguhan dalam menghadapi stres ataupun bangkit dari tekanan emosi (Masten dan Coatsworth, 1998 dalam Kalil 2003). Dalam konteks belajar sebagaimana tampak pada partisipan penelitian ini, resiliensi akademik merupakan proses dinamis yang mencerminkan kekuatan dan ketangguhan seseorang untuk bangkit dari pengalaman emosional negatif, saat menghadapi situasi sulit yang menekan atau mengandung hambatan signifikan dalam aktivitas akademik yang dilakukan.

Temuan pertama penelitian ini telah menunjukkan adanya tiga pengalaman negatif yang dirasakan sebagai kesulitan utama dalam menyelesaikan studi. Baik benturan antar peran, problem dengan pembimbing dan penguji, maupun persoalan dalam pelaksanaan penelitian, seluruhnya pernah dialami oleh partisipan dalam frekuensi, intensitas dan rentang waktu yang berlainan. Temuan penelitian ini semakin menegaskan sejumlah hasil penelitian terdahulu yang telah menguraikan bahwa proses studi doktoral dan segala seluk beluknya memang memuat berbagai macam stresor yang cukup sulit untuk dilalui mahasiswa. Bitzer (2007), Ahem dan Manathunga (2004) telah mengidentifikasi berbagai tantangan dan kesulitan para mahasiswa doktoral di negara yang berbeda.

Sebagaimana temuan riset terdahulu (Johnson, dkk, 2008; Offstein, dkk, 2004; Raddon, 2002), benturan waktu antar beberapa tugas dari peran-peran yang sedang dijalani akan memunculkan konflik dalam diri mahasiswa. Konflik yang terus berulang tidak terselesaikan secara efektif akan berkonsekuensi pada kelancaran dan lamanya waktu penyelesaian studi (Hyun et al., 2006; Johnson, dkk, 2008).

Terkait dengan problem dengan pembimbing, menurut Ahem dan Manathunga (2004) seringkali terjadi ketika mahasiswa kurang memiliki kemampuan berkomunikasi 
dan membangun relasi yang baik, ketidaksiapan dengan materi yang akan diteliti sehingga kemudian berganti-ganti topik dalam waktu yang cukup lama. Total jumlah penguji pada setiap ujian doktoral di Universitas Airlangga dan di Indonesia pada umumnya yang cukup banyak juga dirasakan partisipan semakin menyulitkan karena mahasiswa harus mampu menyatukan atau mencari jalan tengah atas masukan-masukan yang kadangkala tidak sejalan. Ahem dan Manathunga (2004) menyatakan bahwa seringkali problem dengan pembimbing maupun penguji ini juga dipicu oleh kurangnya kemampuan mahasiswa dalam berkomunikasi dan membangun relasi yang baik.

Sementara itu kategori problem ketiga yang berkenaan dengan berbagai benturan dalam pelaksanaan penelitian memiliki keterkaitan dengan hasil penelitian Mouton (2001). Penelitian tersebut menemukan bahwa salah satu kesulitan berat yang kerap ditemui oleh mahasiswa doktoral adalah kesulitan lapangan, yang muncul karena mahasiswa tidak cukup memiliki ketrampilan dalam meneliti. Mouton (2001) berdasarkan hasil studinya mengemukakan, pada umumnya tantangan dalam pendidikan doktor juga akan dirasakan sebagai kesulitan yang cukup berat ketika mahasiswa tidak membuat perencanaan studi dengan baik, kurang mampu mengelola diri, memiliki kelemahan dalam ketrampilan meneliti dan penulisan akademik, serta memiliki problem personal.

Lebih lanjut, berbagai literatur telah mengulas bahwa proses resiliensi melibatkan keberadaan faktor-faktor psikologis, baik yang berperan sebagai faktor risiko maupun faktor protektif (VanBreda, 2001; Kalil, 2003). Faktor risiko mengarahkan pada mekanisme yang dapat memunculkan akibat-akibat yang bersifat problematik. Luthar (1999, dalam Kalil, 2003) mendefinisikan faktor risiko sebagai variabel yang memfasilitasi munculnya problem perilaku, sebagai respon yang lebih lanjut dari stres. Sebaliknya, faktor protektif merupakan variabel potensial yang berfungsi mencegah dan menanggulagi berbagai hambatan, persoalan, dan kesulitan dengan cara-cara yang efektif (Hogue dan Liddle 1999; Masten dan Braswell 1991).

Hasil analisis data dalam penelitian ini mendukung hasil studi terdahulu (Crews, dkk, 2007) yang menemukan bahwa pada dasarnya antara faktor risiko dan protektif adalah ekstrim yang berlawanan dalam suatu rentang variabel atau konstrak yang sama. Faktor risiko berada pada ekstrim negatif yang menunjukkan lemahnya kapasitas dari variabel tersebut, sedangkan faktor protektif berada pada ekstrim berbeda dengan positifnya keberadaan variabel tersebut dalam diri individu.

Mahasiswa yang resilien adalah mahasiswa yang berhasil mengatasi berbagai macam risiko dalam studi dengan cara-cara yang adaptif, juga mampu menyeimbangkan antara pemenuhan tuntutan akademik dengan tuntutan sosialnya yang lain. Temuan akhir dari penelitian ini sedikit banyak telah menggambarkan bagaimana cara-cara adaptif yang dimaksud, yakni melalui beberapa bentuk perilaku dalam mengatasi berbagai situasi yang menekan serta langkah-langkah untuk melakukan penyesuaian dalam diri pribadinya. Hasil penelitian ini selanjutnya akan dapat dimanfaatkan untuk merumuskan upaya yang efektif dalam memberikan pendampingan proses studi mahasiswa doktoral secara lebih tepat.

\section{Simpulan}

Hasil penelitian menunjukkan bahwa resiliensi akademik akan dimiliki apabila mahasiswa doktoral mampu beradaptasi secara positif terhadap berbagai pengalaman 
negative yang menekan dan menghambat selama proses studi. Tiga pengalaman negatif yang utama dirasakan oleh seluruh partisipan, adalah: Problem pembagian waktu antar peran, problem dengan pembimbing dan penguji, dan problem dalam pelaksanaan penelitian. Adapun adaptasi positif yang dimaksud terdiri dari dua kategori, yakni dengan cara mengutamakan respon perilaku positif dalam situasi yang menekan dan melakukan penyesuaian personal dalam diri individu.

\section{Daftar Pustaka}

Ahern K., \& Manathunga, C. (2004). Clutch-starting stalled research students. Innovative Higher Education, 28(4), 237-254.

Bireda, A.D. (2015). Challenges to the doctoral journey: a case of female doctoral students. Open Praxis, Vo.7, Issue 4, October-December 2015, pp. 287-297.

Bitzer, E.M. (2007). Supervising higher degrees as a scholarly practice. South African Journal of Higher Education, 21(8), 1010-1019.

Boatman, M. (2014). Academically resilient minority doctoral students who experienced poverty and parental substance abuse. http://scholarworks.waldenu.edu/dissertations.

Boyatzis, R.E. (1998). Transforming qualitative information: Thematic analysis and code development.

Castro, V., Cavajos Jr. J., Garcia, E.E., \& Castro, A.Y. (2011). The road to doctoral success and beyond. International Journal of Doctoral Studies, Vol. 6, 2012, 5277.

Crews, S.D., Bender, H., Cook, C.R., Gresham, F.M., Kern, L., \& Vanderwood, M. (2007). Behavioral Disorders in Children and Adolescents: A Mega Analytic Synthesis. Behavioral Disorders, 32 (2), 64-77.

Ezebilo, E.E. (2012). Challenges in postgraduate studies: Assessments by doctoral students in a Swedish University. Higher Education Studies, Vol. 2, No. 4, 2012, 49-57.

Fuerth, K.M. (2008). Resiliency in academically successful latina doctoral students: Implication for Advocacy. Graduate Theses and Dissertation. http://scholarcommons.usf.edu/etd/255.

Golde, C.M., \& Gallagher, H.A. (1999). The challenges of conducting interdisciplinary research in traditional doctoral programs. Ecosystems (1999), 2: 281-285.

Hyun, J. K., Quinn, B. C., Madon, T., \& Lusting, S. (2006). Graduate student mental health: Needs assessment and utilization of counseling. Journal of College Student Development, 47, 247-266. http://dx.doi.org/10.1353/csd.2006.0030.

Johnson, B., Batia, A. S., \& Haun, J. (2008). Perceived stress among graduate students: Roles, responsibilities, \& social support. VAHPERD Journal, 29(3), 31-36.

Jumlah doktor di Indonesia tak sebanding jumlah penduduknya. (2017). https://tirto.id/jumlah-doktor-di-indonesia-tak-sebanding-jumlah-penduduknyackK9, 15 Maret 2017. 
Kalil, A. (2003). Family resilience and good child outcomes. Wellington: Ministry of Social Development.

Kemenristekdikti genjot dosen bergelar doktor. (2016). http://www.kopertis12.or.id/2016/10/15/kemenristekdikti-genjot-dosen-bergelardoktor.html, 10 Oktober 2016.

Leonard, D. (2001). A woman's guide to doctoral studies. Buckingham: Open University Press.

Mouton, J. (2001). How to succeed in your masters and doctoral studies. Pretoria: Van Schaik Publishers.

Moyer, A., Salovey, P, \& Casey-Cannon, S. (1999). Challenges facing female doctoral students and recent graduates. Psychology of Women Quarterly, 23 (1999), 607630 .

Offstein, E. H., Larson, M. B., McNeill, A. L., \& Mjoni M. H. (2004). Are we doing enough for today's graduate student? The International Journal of Education Management, 18(7), 396-407.

Oswalt, S., \& Riddock, C. (2007). What to do about being overwhelmed: Graduate students, stress and university services. College Student Affairs Journal, 27(1), 24-44.

Peraturan Rektor Universitas Airlangga Nomor 21 Tahun 2014 Tentang Pedoman Pendidikan Program Doktor Universitas Airlangga.

Percy, A. (2014). Studying PhD: Don't suffer in silence. http://www.theguardian.com/higher-education-network. 25 Maret 2014. Diakses Tanggal 20 Maret 2016.

Pyhalto, K., Toom, A., Stubb, J., \& Lonka, K. (2012). International Scholarly Research Notice (ISRN) Education, Vol. 2012, Article ID 934941.

Raddon, A. (2002). Mothers in the academy: positioned and positioning within discourses of the 'successful academic' and the 'good mother'. Studies in Higher Education, 27, 387-403.

Richardson, G. E. (2002). The Metatheory of Resilience and Resiliency. Journal of Clinical Psychology, 58(3), 307-321.

Siregar, E. (2014). Waendikbud: Indonesia ketinggalan SDM bertitel doktor. http://www.antaranews.com/berita/421689/wamendikbud-indonesiaketinggalan-sdm-bertitel-doktor, 1 Maret 2014. Diakses tanggal 22 Juni 2016.

Sivakumaren, K.S. (2014). Writing research articles: Challenges for doctoral students, teacher, and LIS professionals in India. Chinese Librarianship: an International Electronic Journal, 37. URL: www.iclc.us/cliej/c137sivakumaren.pdf.

Smith, R. L., Maroney, K., Nelson, K. W., Lable, A., \& Abel, H. S. (2006). Doctoral programs: Changing high rates of attrition. Journal of Humanistic Counseling, Education and Development, 45(1), 17-31.

Stratton, J. S., Mielke, A., Kirshenbaum, S., Goodrich, A., \& McRae, C. (2006). Finding a balanced life: Factors that contribute to life satisfaction in graduate students. Journal of College \& Character, 7(8), 1-10. 
Sumardiyani, W.R. (2015). Indonesia kekurangan doktor. http://www.pikiranrakyat.com/pendidikan/2015/10/08/345392/indonesia-kekurangan-doktor, 8 Oktober 2015. Diakses tanggal 22 Juni 2016.

Toews, J. A., Lockyer, J. M., Dobson, D. J., Simpson, E., Brownell, A. K. W., Brenneis, F., MacPherson, K. M., \& Cohen, G. S. (1997). Analysis of stress levels among medical students, resident, and graduate students at four Canadian schools of medicine. Academic Medicine, 72, 997-1002.

Tugade, M.M., Fredricson, B.L., \& Barrett, L.F. (2004). Psychological resilience and positive emotional granurality: Examining the benefits of positive emotions on coping and health. Journal of Personality, 72:26, December 2004.

VanBreda, A.D. (2001). Resilience theory: A literature review. Pretoria: South African Military Health Service, Military Psychological Institute, Social Work Research and Development.

Vekkaila, J., Pyhalto, K., \& Lonka, K. (2013). Experience of disengagement - a study of doctoral students in the behavioral sciences. International Journal of Doctoral Studies, Vol. 8, 2013, pp. 61-81. 